\title{
The Obama Phenomenon: How Past and Present Resonate
}

\section{Citation}

Kenneth W. Mack. The Obama Phenomenon: How Past and Present Resonate, J. of Blacks in Higher Educ. 99 (2004).

\section{Permanent link}

http://nrs.harvard.edu/urn-3:HUL.InstRepos:34816668

\section{Terms of Use}

This article was downloaded from Harvard University's DASH repository, and is made available under the terms and conditions applicable to Other Posted Material, as set forth at http:// nrs.harvard.edu/urn-3:HUL.InstRepos:dash.current.terms-of-use\#LAA

\section{Share Your Story}

The Harvard community has made this article openly available.

Please share how this access benefits you. Submit a story.

\section{Accessibility}




\title{
The Obama Phenomenon: How Past and Present Resonate*
}

\author{
Journal of Blacks in Higher Education, Autumn 2004, p. 99.
}

by Kenneth W. Mack**

Barack Obama was catapulted to national prominence, in part, because of his skill at building bonds of empathy with supporters from a seemingly impossibly broad political base. Conservatives marveled at his use of language and metaphors that resonated with their core beliefs. Liberals and progressives believed that the rise to prominence of a self-identified African American with impeccable civil rights credentials represented a triumph for their own core agenda. People with a wide variety of viewpoints saw something of themselves in Barack and viewed him as a person who understood their feelings and aspirations even when they did not agree completely with him on politics and policy. Most observers believed that these skills were a significant part of the reason for his triumph over a crowded field of seemingly formidable candidates. If all this appears to be an analysis of Barack Obama's victories in the primary and general elections for the Illinois Senate seat, it is not. Instead, it describes the event that first thrust Barack into the national spotlight - his election as the first black president of the Harvard Law Review in 1990.

Barack and I knew each other probably from the first day we both entered Harvard Law School in the fall of 1988. We were in the same section, and our friendship grew during that year and during the next two when we served together on the editorial staff of the law review. From the beginning, he was a striking figure. He had a way of seeming older and wiser than the three years that separated our birthdates. Everyone knew that he had been a community

\footnotetext{
${ }^{*}$ Copyright $\odot$ 2004, by Kenneth W. Mack.

** Professor of Law, Harvard Law School; kmack@law.harvard.edu; (617) 495-5473.
} 
organizer in Chicago, but he also seemed to be wise in the ways of the larger world, and could talk about international politics as easily as low-income neighborhood development. Of course, he also had the unusual name - the "skinny kid with the funny name" as he calls himself now. I thought of him as African American, and only slowly did I learn something of the peripatetic background and multiracial origins that lay behind the façade of my fellow student who seemed to have a perfect (to my mind) mid-western black accent. The empathy was already there. There was one professor in particular, with whom most of the section seemed uncomfortable. Barack and I were part of the few who actually seemed to bond with him - my bond was intellectual but Barack's seemed to be something deeper. It was customary for the section to give each professor a gift at the end of the semester. This professor presented a problem in this regard since few students were comfortable with him. Our section, not surprisingly, selected Barack to give him his gift. The next year, I would get to see Barack work his magic on a larger stage - the editorial staff of the law review.

I spent the following summer doing human rights work in South Africa and thus arrived several weeks late to the law review editors' training session. By the time I returned to Cambridge, Barack had already impressed both the second and third year student editors. He had participated in a committee that would plan the annual issue devoted to some new development in law, and was also holding forth in the forum where impressions were formed quickly among the staff - the editors' lounge. The lounge was a place to relax on the law review - it had a television, copies of the New York Times, our mailboxes and bagels in the morning but it was also the place where assessments were quickly made by a group of very ambitious people. Barack had already made a quite good impression there with a worldly-wise way of talking about everything from current events to theories of law. Like all of us, he had ambition, 
but he never seemed that way. This was an attitude that many editors failed to internalize but it was key to winning election to the presidency of the review.

The African American editors had been strategizing to elect one of our own to the presidency for several years, and it was not an easy task. Being on the law review was the most race-conscious experience of my life, and race-based attitudes and prejudices crossed political and ideological lines among the law students comprising its staff. Many of the white editors were, consciously or unconsciously, distrustful of the intellectual capacities of African American editors or authors, and simply being taken seriously as an intellectual was often an uphill battle. Yet, a black editor, Crystal Nix (now Crystal Nix-Hines, a Hollywood screenwriter) had won election to a high editorial post the year before and with that precedent, four black editors threw their hats in the ring for the election to the presidency in the winter of 1990 . Seventeen editors eventually decided to run for the position.

There were many elements involved in Barack's eventual victory, but the one moment that stands out to me was a vote, taken among the editors a few weeks before the election, that divided liberals and progressives from conservatives among the editorial staff. The law review, like America today, was sometimes bitterly divided along political lines, although there the liberals and progressives were in the clear majority. We argued about everything from affirmative action to the politics of legal scholarship. The conservatives lost this particular vote and many of us, myself included, were inclined to talk no further with them about it. Yet Barack followed up the vote by publicly offering to discuss the issue further and to find common ground with the conservatives, while seeming to empathize with their views. Not everyone on the winning side agreed with that tactic, but it paid dividends. I remember vividly a moment during the presidential election when a conservative editor who I had never known to support a black 
editor or a black author rose to pledge his firm support behind Barack, who everyone knew was a liberal-progressive.

Barack, of course, won the election handily with an incredibly broad range of supporters. It was a moment of triumph that crossed racial and political lines, as well as about every other demographic line among the editors. When Barack walked into the room where the election took place to accept the results, I was the first to greet him and the two of us hugged for several minutes. Tears rolled down both of our faces, as well as those of many in attendance. I was among the large group of candidates whom Barack had trounced in the election, and I believe that had our positions been reversed, the empathy that I had seen so often would have induced Barack to do the same thing for me.

We talked about the significance of his victory many times during the next year. We would often grab a meal together at a small sandwich shop in Harvard square and chat about everything from basketball to our future professional plans. I remember telling him that I had decided to forego a career as a civil rights attorney to pursue one in academia, while Barack told me that he was turning down the expected next step for the president - a clerkship with a prestigious appellate judge or a Supreme Court Justice - to get back to Chicago and to the community with whom he empathized. Neither of us knew whether our choices would pay dividends in the future, or whether Barack's achievement would remain a symbolic victory or carry the seeds of something greater.

When I saw Barack give the keynote address at the Democratic National Convention, it all seemed eerily familiar, albeit acted out on the largest stage of his career: the broad coalition of support that had pushed him to victory in a hotly contested election, the attention from the national news media and public, even the same mid-western accent and idiom 
that I had heard so often in law school. But what seemed most familiar about the speech were the broad themes of the politics of empathy - the idea that this was a candidate who crossed demographic lines in his own background and who was urging his fellow Americans to do the same in their politics. It was a singularly effective speech and many people have asked me, as someone who knows him, whether his political aides wrote it for him. I have answered them conclusively. The speech was pure Barack, although, like most public figures, he undoubtedly had assistance. It was a talk whose broad themes I have heard him deliver, in words and in actions, since our first days of law school in the fall of 1988.

I should, however, not push the analogy between past and present too far. In truth, the law review was a far different venue than the one that Barack currently inhabits. There political discussions centered around the types of scholarship we should publish, or internal editorial policies of the journal. In Barack's current venue, the politics of empathy have far greater potential costs and benefits to the American and international public. Empathy can degenerate into watered-down politics, seeking the lowest common denominator and detached from a positive program for progressive change, as in Bill Clinton's legacy to liberal politics and to the Democratic party. Empathy can also be the basis for assembling a broad coalition of supporters around a concrete program with core principles. I believe that history will judge Barack by which type of the politics of empathy he ultimately produces. If it is solely the former, he will still be a noteworthy figure in African American, and American, history and politics - the first black president of the Harvard Law Review and the first black male Democrat to reach the Senate in American history. If it is the second, he may be a "first" of another sort an African American politician who changes the nature of black politics, and American politics as well. I believe that he has it in him to do so. 